\title{
Et forslag til en grundtvigsk lærd skole 1832
}

\author{
Af Henning Heilesen
}

N.F.S. Grundtvig blev i årene $1826-1828$ to gange indviklet i stridigheder vedrørende skolespørgsmå $\left.1^{1}\right)$. Første gang, i I826, blev han truet med en ny injurieproces (foruden den løbende rejst af $H . N$. Clausen), fordi han havde kritiseret religionsundervisningen i Aftenskolen for Piger på Christianshavn. Anden gang, i 1828, blev han af facob Lindberg indblandet i en strid på Borgerdydskolen på Christianshavn. Sandsynligvis på baggrund af disse stridigheder luftede han i et brev af 22. juli 1828 over for P.A. Fenger tanken om at rejse »en ny Skole, hvori christne Folk raadte for hele Underviisningens Gang«.

Tanken om en sådan skole søgtes virkeliggjort, efter at P. A. Fengers yngre broder 7 . F. Fenger i december i 83 I var vendt tilbage fra en treårig udenlandsrejse, som bl. a. havde ført ham til Grækenland. Han var i den følgende tid virksom for at udbrede kendskab til dette land, som i 1830 havde genvundet sin selvstændighed, og til dets sprog, bl. a. ved udgivelse af »Om det nygræske Folk og Sprog « (1832) og ved at give kursus i nygræsk. Grundtvig gav sig under hans vejledning til at studere sproget og var meget optaget af det, fordi det modsat de døde oldtidssprog levede på menneskers tunge ${ }^{2}$ ). Dette bragte ham på den tanke, at græsk, især nygræsk, burde være det vigtigste fremmedsprog i de lærde skoler og ikke latin, som det dengang var tilfældet ${ }^{3}$ ). I samråd med Grundtvig og J. F. Fenger udarbejdede hans sønners huslærer, cand. theol. C.H. Muus, der nylig

I. K. E. Bugge: Skolen for livet s. 236 anm. 119, jfr. Kaj Baagø: Magister Jacob Christian Lindberg s. I 5 anm. Io.

2. F. Elle Jensen: Ferdinand Fenger s. 33, jfr. Helge Toldberg: Grundtvig som filolog s. 49 .

3. Grundtvig gav ved den tid udtryk derfor $\mathrm{i}$ indledningen til »Nordens $\mathrm{My}$ thologi« (Grundtvigs skoleverden i tekster og udkast, udg. af K. E. Bugge I 236). 
havde fået udgivet en oversættelse af Eusebs kirkehistorie, et forslag til en lærd skole, hvor græsk skulle træde i stedet for latin, og hvor dansk og historie skulle være hovedfagene.

Plakat af ig. juli i805 om oprettelse af Direktionen for Universitetet og de Lærde Skoler indeholdt følgende bestemmelse: »Saa skal og herefter intet nyt Privat-Institut, hvis Formaal er Forebereedelse til academisk Studering, kunne oprettes uden Vor allerhøieste Tilladelse; til hvilken Ende Planen hertil hvergang foreløbigen bør indsendes til Directionens Prøvelse.« I overensstemmelse dermed indsendte Muus 30 . august ${ }_{1} 83^{2}$ sin plan til direktionen med følgende skrivelse ${ }^{4}$ : :

»Efter flere udvortes fra givne Opfordringer og Anledninger har jeg givet den Tanke Rum, at det maaskee kunde være min Bestemmelse at søge mit Arbeide og mit Brød i Skolefaget. Jeg har længe holdt mig tilbage, men er omsider bleven enig med mig selv og nærer nu det Ønske, i Forbindelse med DHrr. Pastor Grundtvig og Licentiatus Theologiæ Fenger, efter at vi en Tid lang have drøftet Sagen med hinanden, - at aabne en Skole her i Staden for lærd Underviisning, hvilket Ønskes Opfyldelse beroer paa den høie Direction, jeg herved tager mig den Frihed at henvende mig til, for at faae den fornødne Tilladelse.

Planen til den Skole, jeg attraaer at oprette, har jeg den Ære at vedlægge til Prøvelse, om den maatte finde gunstigst Bifald.

Foruden hvad bemeldte Plan indeholder, vil jeg endnu her gjøre Directionen opmærksom paa, at det, for at Grunden kunde blive lagt med den Eenhed, som Foretagendet, især forfra, kræver, - er en Aftale mellem Grundtvig, Fenger og mig, at vi Tre, for det Første, med Undtagelse af Skrivning og Regning, skulde dele Underviisningen med hinanden, uden Mellemkomst af fremmede Lærere, der først senere, ved forøget Arbeide, maatte tages til Hjælp.

Jeg ansøger altsaa den høie Direction om Tilladelse til at udføre min Plan og om Tilstaaelse af de Rettigheder og Friheder, som dertil maatte være mig fornødne.

København d. $30^{\text {te }}$ August 1832 .

Til

Den høie Direction

Underdanigst

for Universitetet

C. H. Muus,

og de lærde Skoler.

Candidatus Theologiæ.»

Muus' plan til en lærd skole så således ud:

》Skolen skulde, efter almindelig Skik, tage sin Begyndelse med Drenge paa 9-1o Aar, eller derunder, og, som sædvanlig, gjennem visse Grader bringe dem til den Modenhed, at de, naar Alderen dertil kom, kunde faae Adgang til

4. Denne skrivelse samt planen findes i Universitets- og Skoledirektionens arkiv, Universitets- og skolesager AA I 103 (RA). 
Høiskolen $^{5}$ ). Maalet blev altsaa det samme som de almindelige lærde skolers.

Istedetfor at der ellers begyndes med Latin, skulde her gjøres Forsøg paa at begynde med Græsk, og det er tillige Hensigten at prøve, om der muligen kunde vindes Noget ved at sætte Nygræsk som levende Sprog i Forbindelse dermed.

Til flere fremmede Sprog end Disse skulde Underviisningen fra Først af ikke udstrækkes; men efterhaanden maatte naturligviis, i den Orden og den Grad, som Nødvendigheden af sig selv vilde medføre, optages ethvert andet, saavel ældre som nyere Sprog, der gjøres til Betingelse for academisk Borgerret.

Modersmaalet og Historien skulde forfra og hele Skolen igjennem behandles som en Hovedsag.

Iøvrigt vilde de andre Skolefag, som ogsaa have deres Betydning med Hensyn paa Menneskets Dannelse, saavelsom enhver Kunst og eller Færdighed, der maatte agtes nødvendig for den aandelige eller legemlige Udviklings Skyld, til den Tid og paa den Maade, Erfaringen bedst lærer, tilbørligen blive indlemmede i Underviisningens Cursus; men for Øieblikket vilde en til alle Sider udviklet og begrændset Forestilling om Skolens Indretning og Virksomhed heeltigjennem, om den havdes, dog sikkert være utidig.

Naar det første Stadium i Underviisningen var gjennemgaaet, er det Meningen, at et nyt Sæt Drenge skulde modtages, og saaledes fremdeles, indtil Skolen blev fuldstændig. Skulde, hvad ikke er at formode, flere Disciple blive anmeldte, end der under Ening kunde undervises, maatte Begyndelsen gjøres med jevnsides Afdelinger; men io Aars Alder, eller den Udviklnig, Børn i den Alder almindeligviis kan antages at have naaet, vilde blive Grændsen, der ved Optagelsen for det Første ikke kunde overskrides.

Det bemærkes endelig, at det af en saaledes paa fri Haand anlagt Skole, naar den kun ellers kom til fuld Virksomhed, vel kan haabes, at De, der fik gjennemgaaet alle dens Classer, vilde være modne for Høiskolen, og dette skulde, som sagt er foran, ogsaa være det nærmeste Maal, - men at derimod Ingen midtveis paa nogetsomhelst Punct vilde kunne passes ind i de almindelige Skoler.

Af Bøger er det Hensigten, ved den Historiske Underviisning at begynde med Grundtvigs Historiske Børnelardom og det tilsvarende historiske Kort, kaldet Tidens Strom, samt passende Stykker af samme Forfatters Historiske Riimkronike. Til Grundlag i Geographien blev at vælge een af de almindelige Skolebøger. I Grask skulde for det Første, efter Langes Grammatik, Johannis Evangelium lægges til Grund, i Forbindelse med een eller anden af de Læsebøger, som haves. Ved Religionsunderviisningen vilde Grundtvigs Bibelkrønike blive brugt i Forening med det Nye Testamentes historiske Bøger. Saxo og Snorro, Bjowulfs Drape og een eller anden Exempelsamling kunde der ved Underviisningen i Dansk gjøres Brug af.«

Grundlaget for denne plan var undervisningen af Grundtvigs sønner. Denne kendes ellers kun fra optegnelser af Marie Blom og

5. Højskolen, d. e. universitetet. 
Grundtvigs svigerdatter Laura Grundtvig ${ }^{6}$ ), begge nedskrevet godt $5^{\circ}$ år efter den tid, der her er tale om. Laura Grundtvigs meddelelser er endog på anden hånd, baseret på oplysninger af hendes mand, Svend Grundtvig. Muus' plan bekræfter, hvad Marie Blom og Laura Grundtvig meddeler om det, fohan og Svend Grundtvig lærte af deres fader, bistået af Muus o. a. Af fremmede sprog lærte de kun ét, nemlig græsk $^{7}$ ). Marie Bloms oplysning, at de læste Johannesevangeliet i grundsproget, før de lærte den lille tabel eller at skrive skønskrift, er muligvis en overdrivelse, men vist ikke langt fra sandheden; dette kan ses af, at Muus foreslog dette evangelium som den første sammenhængende græske tekst $\mathrm{i}$ stedet for Xenofons Anabasis. Grundtvigs sønner lærte ikke grammatik ${ }^{8}$ ), men som praktisk pædagog indså Muus nødvendigheden af en sådan og foreslog derfor brugen af F. O. Langes »Det græske Sprogs Grammatik«, forløberen for C. Bergs græske formlære, og af en græsk elementarbog.

At dansk og historie hele skolen igennem skulle betragtes som hovedfag, var helt i Grundtvigs ånd. Det var naturligt for Muus at foreslå at bruge Grundtvigs oversættelser af Saxo, Snorres »Heimskringla« og det angelsaksiske digt »Beowulf « ved undervisningen i dansk; i hvert fald Saxo og Snorre blev brugt ved undervisningen af Grundtvigs sønner $\left.{ }^{9}\right)$. Ved deres undervisning brugtes i historie Grundtvigs »Historisk Børne-Lærdom《, der udkom I. gang I829 og i sin forfatters levetid oplevede $\mathbf{i}$ alt 7 udgaver, sidste gang 1867 . I forbindelse dermed brugtes oversigtstavlen $\gg$ Tidens Strøm $\left.\ll^{10}\right)$. Ligeledes nævnes i Muus' plan »Krønike-Riim til Børne-Lærdom«, som den I. udgave ( 1829 ) hed; 2. udgave ( 1842 ) havde titlen »Krønike-Riim til levende Skolebrug «. Disse »Krønike-Riim« lod Grundtvig sine sønner lære udenad, for at det mundtligt meddelte kunne fæstne sig i hukommelsen. Hvad den ældste søn, Johan Grundtvig, mente om dem, vides ikke, men Svend Grundtvig lærte dem med stor fornøjelse og kunne endnu på sine gamle dage flere af dem udenad. I efterskriften til 3. udgave (1875) udtalte han, at han havde elsket dem fra sin tidligste barndom $\left.\ll^{11}\right)$.

6. Grundtvigs Erindringer og Erindringer om Grundtvig, udg. af Steen Johansen og Henning Høirup s. I 40, $145 \mathrm{ff}$.

7. Sst. s. 146.

8. Sst. s. $146 \mathrm{f}$.

9. Sst. s. 147 .

Io. Sst. s. I 46,29 I.

I I. Nævnte udgave s. 305 . 
Geografi lærte Grundtvigs sønner i sammenhæng med historie; Muus anså det dog for nødvendigt at nævne det særskilt. Det var dog vist meningen, at dette fag skulle læres i sammenhæng med historieundervisningen, da det $\mathrm{i}$ planen nævnes lige efter historie.

Undervisningen i den påtænkte skole skulle altså have en overvejende historisk karakter. Dette gjaldt også religionsundervisningen, hvor Muus ville bruge Grundtvigs »En liden Bibel-Krønike for Børn og Menig-Mand« som grundlag; den var udkommet I. gang I8I4 og blev genudgivet i omarbejdet skikkelse 1828 . Grundtvigs sønner fik deres religionsundervisning gennem mundtlig fortælling af bibelhistorien, og »Bibelkrøniken« opfattedes som et kort udtog af det, der var blevet fortalt mundtligt ${ }^{12}$ ). Det var vistnok meningen, at hovedvægten skulle lægges på den mundtlige fortælling. Herpå tyder bemærkningen i planen, at det $\mathrm{Ny}$ Testamentes historiske bøger skulde bruges i forening med »Bibelkrøniken«.

Mærkeligt nok stod der intet i planen om brug af salmer og sange, især $\mathrm{i}$ betragtning af, hvor meget der er blevet sunget $\mathrm{i}$ de grundtvigsk prægede skoleformer. Grundtvig selv var aldeles umusikalsk, men blandt initiativtagerne til denne skoleplan var der dog én, der havde en udviklet musikalsk sans, nemlig Fenger ${ }^{13}$ ). Ved denne tid udgav L. C. Hagen i nært samarbejde med Grundtvig »Historiske Psalmer og Riim til Børne-Lærdom«.

Muligheden for at undervise andre fag end de, der nævntes i planen, lod Muus stå åben. Her tænkes vist særlig på de fag, Grundtvig nærede særlig uvilje mod, nemlig latin og matematik. I indledningen til »Nordens Mythologi« fordømte Grundtvig latiniteten som »den Romersk-Italienske Livs-Plage og Aands-Fortærelse $\ll^{14}$ ) og »den slet nedmanede Jettes Gienfærd, opsteget af de Pontinske Moser $\ll^{15}$ ). Dog var det dengang ikke muligt at blive student uden kendskab til latin, så en skole, der ønskede at dimittere til studentereksamen, kunne ikke undgå dette fag på timeplanen. Grundtvigs indstilling over for matematik kendes fra en udtalelse $\mathrm{i} \gg$ Mands Minde« 1838; han kaldte her dette fag »den dødeste og tommeste af alle vore Kundskaber $\left.\ll^{16}\right)$.

12. Grundtvigs Erindringer og Erindringer om Grundtvig s. I $45 \mathrm{f}$.

13. F. Elle Jensen anf. værk s. I 9.

14. Grundtvigs skoleverden I 227.

I5. Sst.

16. Cit. efter Ernst J. Borup og Fr. Schrøder: Haandbog i N. F. S. Grundtvigs Skrifter II I $28 \mathrm{f}$. 
Direktionen for Universitetet og de lærde Skoler bestod dengang af to embedsmænd, nemlig I. deputeret i Slesvig-Holsten-Lauenborgske Kancelli Andreas Biørn Rothe og kommitteret i Rentekammeret Jens Olaus Hansen, samt af hof- og slotspræst, senere biskop 7. P. Mynster. Ingen af dem havde nogen tilknytning til universitetet og de lærde skoler. Professor Laurids Engelstoft var udtrådt af direktionen i maj $183^{2}$ efter at han var blevet medlem af Konsistorium ${ }^{17}$ ) (han blev atter medlem af den 1840 ).

Skoleplanen blev 8. september sendt til Konsistorium med anmodning om rektors og professorernes betænkning. Universitetets daværende rektor var den teologiske professor fens Moller; han sendte 9 . september sagen videre til det filosofiske fakultets dekan, professor i filosofi $F$. C. Sibbern, idet han anmodede fakultetet om at udtale sig $\left.^{18}\right)$. Sibbern afgav følgende erklæring, inden han lod sagen cirkulere:

»Idet jeg sætter nærværende Sag, hvorover det philosophiske Facultets Erklæring er forlangt, i Circulation, undlader jeg ikke at give min Betænkning om Sagen.

At der gjøres et Forsøg paa at begynde den lærde Underviisning med Græsk istedetfor med Latin, kan man vist ikke modsætte sig; men at Nygræsk læres ved Siden af det gamle Græsk, kan vist ikke blive Andet end til Skade og Forvirring med Hensyn til det sidste; ogsaa har det den Betænkelighed, at Studiet af Nygræsk vel bør være noget mere udbredt imellem de Aldre $i$ et Folk, end det er hos os, førend man lader det optage en Plads i den forste BørneUnderviisning.

En Lærer, der forstaaer sin Videnskab og bringer Aand med til Underviisningen deri, vil sikkert kunne lægge et godt Grundlag for Underviisningen i Historie ved at følge Planen i dette Stykke; ogsaa vil det vel ikke feile, at en forbedret Udgave af Grundtvigs historiske Børnelærdom, men efter samme Idee, vil blive Frugten. Over Hensigtsmæssigheden af at benytte Grundtvigs Riimkrønike har jeg ingen Dom, da jeg ei har betragtet den i saa Henseende.

At i Græesk Johannis Evangelium skulde læses strax, idetmindste strax efterat de første Elementer vare bibragte, hænger formodentlig sammen med den Plan at begynde med Nygræsken. Dog vilde i al Fald sikkert Matthai Evangelium være at foretrække. Hiint Evangelii Helligdomme maa man ei aabne for tidligt for Børn, endnu mindre tidligt føre dem om på ethvert Punct deri, og levere dem ethvert Stykke deraf i Hænderne. Matthæi Evangelium staar høist passende foran i vort nye Testamentes Bøgers Række.

Til Grundlag i Geographie maatte man vel onske et Grundlag lagt, liigt det, man i Historien vil lægge; nemlig et saadant, hvorved der allerførst lagdes

I 7. G. F. Wegener: Biographiske Antegnelser om Laurids Engelstoft s. I 09.

I 8. Erklæringerne findes i Universitets- og skolesager AA 1 I03 (se note 4). 
an paa at orientere i Henseende til den hele Jord-Overflades Beskaffenhed, Delenes Forhold og de Grundbegreber, der skulle lede i det Enkelte, de Hovedpuncter, hvortil det Enkelte siden skal støttes.

At Religionsunderviisningen begynder med Bibelhistorie er vist godt. Om Grundtvigs Bibelkrønike kan jeg ei dømme. Men hvad det vil sige: »i Forening med det nye Testamentes historiske Bøger« fatter jeg ei. Vil man da ei tage det gamle Testamentes med? Af første Mosebog maatte vel Alt i dets hele Detail - med Undtagelse af de Partier, som for Blufærdigheds Skyld maae skjules, - tages med, og siden af det gamle Testamentes øvrige Bøger det Hensigtsmæssige; ei blot af de historiske, men og af Psalmerne, Salomons Bøger o.s. v.

Hvorledes man kan falde paa at ville lægge nogle Oversættelser deels af Latinen, deels af det saa kaldte Islandske til Grund ved Underviisningen i Dansk, begriber jeg ikke. Ikke at tale om, at de valgte vel maatte komme i Collision med Underviisningen i Historie, især Saxo, i hvis Historie der desuden staae Ting, man ei kan lade Børn læse, f. Ex. i Amleths Historie. Maaskee er der især tænkt paa Wedel Sørensens Oversættelse af Saxo. Men et ypperligt Sprog-Monument fra et Par Aarhundreder tilbage vilde det dog være et aabenbart Hysteron-Proteron ${ }^{19}$ ) at lægge til Grund for den første Underviisning for Børn, som daglig tale og læse et andet Dansk, nemlig vor Tidsalders.

Endelig mener jeg, at hvad den forlangte Bevilling $i$ det Hele angaaer, at der kunde foreslaaes, at man, skjønt man fandt, at der kunde gjøres grundede Indvendinger imod den lagte Plan, dog ikke vilde modsætte sig det Forsøg, der skulde gjøres med den ved at indrette en Skole derefter; men at, dersom Vedkommende vilde gjøre en offentlig Indbydelse til at mælde sig til den, de da maatte paaberaabe sig den givne Tilladelse med Anførelse af de Udtryk, hvori den var given.

Kjøbenhavn d. Iode Sept. I832.

Sibbern.«

Sibbern havde ikke helt forstået planen; f. eks. forestillede han sig, at eleverne skulde læse Saxo i Anders Sørensen Vedels oversættelse fra 1575 og ikke i Grundtvigs. Tanken om at lade græsk træde i stedet for latin måtte særlig vedkomme professorerne $\mathrm{i}$ klassisk filologi, 7. N. Madvig og F. C. Petersen; deres kritik var skarp:

»Den vedlagte Plan for Underviisningen i det paatænkte Institut forekommer mig ingenlunde saa udviklet og bestemt, at jeg i det Hele kan gjøre mig nogen klar Forestilling om Underviisningens Gang og Sammenhæng. Et Par Punkter, hvorpaa synes at være lagt Vægt, kan jeg ikke billige. Nygrcesk anseer jeg ikke blot $n u$ for upassende, men for aldeles uhenhørende til Skoleunderviisningen; det er et historisk Forhold og den græske Oldtids Væsen der skal bevæge os til at lære Græsk; dermed har Nygræsk Intet at gjøre, der som særegent Sprog ingen videre Betydning har (uden for Linguisten ex. prof. ${ }^{20}$ ))

19. Græsk; egentlig det sidste først, her: en bagvendt fremgangsmåde.

20. Forkortelse af ex professo, på embeds vegne. 
end ethvert andet nyere Sprog og næsten ringere end ethvert af disse, saalænge Nygrækerne saa lidet spille en Rolle i den europæiske Cultur; som Hjelpemiddel til at lære Gammelgræsk forekommer det mig at være en lige saa forkeert og unyttig Omvei, som om Nogen for at lære Latin vilde først lære Italiensk. Den ulige Afstand gjør her Intet til Sagen; det er lige underligt at lære en Form, der ikke er den, man vil lære, for siden at lære en anden, naar den første ikke engang er den primitivere, muligen et grundigere Studium af den anden befordrende. Hvad Sprogbrugen uden for Grammatiken angaaer, maa den for de Gamle alligevel altid læres af de Gamle alene.

At begynde med Græsk anseer jeg med Hensyn til den Rolle, som Latin nu engang spiller i vor Cultur og dens Forbindelse med Fortiden, for urigtigt, men kan dog ikke nægte, at det kan være Forsøget værd. Betragter jeg imidlertid Forslaget at begynde med Joh. Evang., maa jeg troe, at Hensigten er ikke at gjøre bekjendt med Grækenland og græsk Litteratur, men at komme snarest muligt til Theologiens lærde Fundament, hvor jeg da ikke kan andet end være bange for Overilelse, især ved at see dette Evangelium valgt, ligesom om man ikke vilde oppebie Sprogformens Opfatning, førend man ledte ind i en ikke blot eenfoldig Læsning af Bibelen.

Ved den historiske Underviisning har jeg betydelige Tvivl om en poetiserende og dertil en individuel Anskuelse stærkt udtrykkende Fremstilling vil lede til den Opfatning af Historien, hvorved den skulde være Fordomsfuldheds og til een Tids Former klæbende Indskrænketheds Bekæmperinde.

Hvad Underviisningen i Dansk angaaer, tiltræder jeg aldeles Hr. Prof Sibberns Yttringer. Ikke at lære sit Folks Sprog at kjende eller at fremsætte sine Tanker i egen naturlig Tale, men at optage i sig en enkelt Personligheds endog med bevidst Stræben antagne Stiil, er det, hvortil Disciplene synes at skulle føres.

Planen forekommer mig at give megen Anledning til Frygt for en stoor Eensidighed og Stræben efter at bemægtige sig Ungdommen for en vis udelukkende Aandsretning, ikke i Troessager, hvor Enhver bør ivrigen lære det, han anseer for det Bedste, men i det Hele; men ved Umuligheden i uden Uretfærdighed at hindre en Privatunderviisning i denne Aand mener jeg, at man ikke burde lægge Hindringer i Veien for Forsøget med et Institut, med den Form i Tilladelsen, som Prof. Sibbern foreslaaer, og med den udtrykkelige Erklæring, at man ved Ex. Art. vilde fordre Disciplene i Besiddelse af det Omfang af Kundskabsstof, som forlangtes af dem, der efter de autoriserede Lærebøger vare underviiste.

d. I3. Septbr 1832 .

J. N. Madvig.

Dersom Betingelsen for at anlægge en lærd Underviisnings-Anstalt er, at der forud til høiere Approbation skal indleveres en Plan, der giver en klar, og i det Væsentlige fuldstændig Kundskab om en saadan Anstalts Øiemed, Maaden hvorpaa, og Midlerne, hvorved man vil naae dette, da kan man vel ikke videre indlade sig med den eller dem, der have indsendt vedliggende Udkast, forinden de indlevere en fuldstændigere og saa vidt muligt detailleret Plan.

Indvender man herimod, at det, som Planen indeholder, er nok til at man 
kan giøre sig en Forestilling om det, der er det Eiendommelige ved den, nægter jeg ikke, at dette $\mathrm{i}$ en vis Betydning er sandt, og det indtil den Grad, at det er klart, at man vil indrette en Separatist-Skole, der vil blive saare forskiellig fra vore sædvanlige Underviisnings- og Dannelses-Anstalter. Hvortil en Dannelse, som den her tilsigtede, dersom den vinder Bifald og Fremgang, rimeligen vil lede dem, der modtage denne Dannelse, er en Betragtning, der vistnok i mere end een Henseende bør tildrage sig vedkommende Autoriteters Opmærksomhed. - Jeg vil blot nævne den Deel af Planen, ifølge hvilken den græske Underviisning skal begynde med Johannes Evangelium i Forbindelse med det nygræske Sprog. Man maae ved en saadan Methode enten slet ingen Hensigt have, eller have en gandske anden, end at bibringe Lærlingen Kundskab i det græske Sprog og den græske Litteratur, thi til dette sidste Øiemed var det dog vel ikke muligt at vælge et forkeertere Middel end det her foreslaaede. Angaaende de øvrige Puncter indskrænker jeg mig til at henvise til de af mine $\mathrm{H}^{\mathrm{rr}}$ Colleger Prof. Sibbern og Prof. Madvig giorte Bemærkninger, men mit Forslag er, at der svares Indsenderen af Ansøgningen, at den indsendte Plan er saa ufuldstændig og ubestemt, at man ikke kan indlade sig paa enten at antage eller forkaste den, forinden en fuldstændigere og tydeligere Plan forelægges. Desuden burde der vel giøres opmærksom paa, at det, som Planen indeholder, for største Delen baade er saa afvigende fra det hidtil Gieldende, og i sig selv af saa betænkelig Beskaffenhed, at man anmoder Ansøgeren nøie at overlægge, om ikke betydelige Forandringer deri skulde være deels nødvendige, deels ønskelige.

Vil Consistorium ikke desto mindre anbefale og den Kongelige Direction for Univ. og de lærde Skoler tillade Indretningen af en Skole efter Planen, som den nu er, saa anseer jeg for nødvendigt, at det sker med den Clausul i Bekiendtgiørelsen, som er foreslaaet af Prof. Sibbern.

d. $20^{\text {de Sept. }} 1832$.

F. C. Petersen.«

Det var at vente, at en mand som Madvig med sin forkærlighed for det latinske sprog ville afvise et forslag om at foretrække græsk frem for latin som skolefag. Bemærkelsesværdigt var det, at også F. C. Petersen, der $\mathrm{i}$ sin videnskabelige produktion væsentlig koncentrerede sig om den græske litteratur, afviste planen. Madvig udtrykte allerede på det tidspunkt sin uvilje mod Grundtvigs skoletanker; $i$ hans frygt for »en stor Eensidighed og Stræben efter at bemægtige sig Ungdommen for en vis udelukkende Aandsretning « er der noget, som peger fremad mod hans karakteristik 16 år efter af den påtænkte højskole i Sorø som »en særskilt, Characteren af Danskhed monopoliserende Underviisningsanstalt $\ll$.

Laurids Engelstoft og H.C. Ørsted nøjedes ikke med at kritisere planen, som Sibbern, Madvig og F. C. Petersen havde gjort, men de benyttede lejligheden til et opgør med Grundtvig og hans disciple: 
»Det eneste, som er mig ret klart i Planen til det Foretagende, for hvilket $\mathrm{dH}^{\mathrm{rr}}$ Muus, Grundtvig og Fenger ville sætte sig i Spidsen, er, at de agte at stifte et formeligt Seminarium for den velbekiendte mystisk-pietistiske, al sand Oplysning som al ægte Videnskabelighed fiendske, i Lutherdommens Navn Protestantismens Aand bekiæmpende, om end i sin Hensigt ikke ilde meente, saa dog i sine Virkninger høist skadelige, for Stat og Kirke lige fordærvelige Separatismus. Kunde det lykkes dette Partie at bemægtige sig ogsaa Opdragelsen og Underviisningen, hvorefter det naturligviis maa stræbe - saaledes som ogsaa Jesuiterne i sin Tid stræbte efter og naaede - saa vilde uden Tvivl det allerfarligste Middel være kommet i dets Hænder.

Dette i Almindelighed. Hvad det Enkelte angaaer, forsaavidt det i den korte, fragmentariske, usammenhængende og skiødesløst udkastede Plan er fremsat, da er det Allermeeste deraf saa eensidigt og forkeert, og derhos saa afvigende fra den Typus, der gielder som Norm for og $\mathrm{i}$ alle vore offentlige og det offentlige Tilsyn underkastede Læreanstalter, at jeg maatte skrive flere Sider fulde for at omtale og bedømme det nogenledes oplysende. Ikkun Tendenzen er det, som giver det Alt en vis Eenhed, der ogsaa skal sikkres ved Lærerpersonalets Eenhed. Jeg fritager mig saa meget mere fra, $n u$ at forklare mig herover, da jeg med mine Colleger forudsætter, at i alt fald den nu indleverede Plan vil blive tilbageviist som et aldeles ufuldstændigt Udkast. - Candidat Muus, som er den, der søger om Tilladelsen, blev Student I8I5 og tog i Aaret 1828 theologisk Examen med Characteren Haud illaudab. Han er bleven noget bekiendt i Anledning af en Præken om »Livet i Christo«, der efter Sagkyndiges Dom er fuld af forvirrede Ideer, og som har fremkaldt advarende Bemærkninger fra retsindige Mænd (s. Maanedsskrift for Literat. I829 I B. S. I9o ff. S 352 ff.). I øvrigt fortiener det endnu at lægges Mærke til, at Hr. Muus har fundet sig foranlediget til sit Foretagende ved »udvortes fra givne Opfordringer $\ll$.

d. 23. Septemb. 1832 .

Engelstoft.

Saa vidt jeg skjønner er enhver af de Indvendinger mine Herrer Colleger have fremsat mod den omhandlede Plan fuldkomment vel grundede; derimod kan jeg ikke være enig med dem i den Eftergivenhed, at foreslaae at en fuldstændigere Plan skulde forlanges af Ansøgeren. Det er med Cand. theol. Muus og ikke med Grundtvig og Fenger vi have at gjøre. Hans akademiske Qvaliteter anbefale ham ikke, hans bekjendte Prædiken stempler ham som et forvirret Hoved, hvem Ungdommens Veiledning ikke bør betroes. Men vilde man end foreslaae at Tilladelsen, efter en indleveret bedre Plan, skulde gives alle 3 nævnte Mænd, saa synes dog deres Personlighed ikke at egne dem til Ungdommens Veiledning. Man kan lade Grundtvigs Aand og Hjerte vederfares al Ret, og dog paastaae at han er et af de mest eensidige og i Meninger lidenskabelige Mennesker. Man kan tilstaae Fenger en agtbar Lærdom, men han er en theologisk Partiemand, som de to Andre. Denne Omstændighed, at de ere heftige Partiemænd, i en saa vigtig Sag som Religionen, synes mig at gjøre det til Pligt for Universitetet at fraraade Ansøgningens Bevilligelse. Lad Partiemændene forsøge at overbevise de Voxne, som kunne eller dog burde 
kunne tænke selv, men at give Børnene i deres Vold er ikke forsvarligt. Den Bemærkning af Etatsraad Engelstoft, at Jesuiterne erholdt saa stor Indflydelse ved at bemægtige sig Underviisningen, synes mig at være særdeles værd at lægge paa Hjerte. Jeg troer at man i en Betroelsespost som Børneunderviisningen er berettiget til at tage stort Hensyn paa Personligheder, og at man dobbelt har denne Ret, naar Personlighederne have givet sig offentligt tilkjende, hvor man altsaa kan tale om aabenbare Kjendsgjærninger, ikke behøver at frygte for at være skuffet af falske Rygter. Men om man endog tilsidesatte alt dette, saa indeholder Planen dog saadanne Urimeligheder, at det ikke synes mig at man behøver mere Beviis paa Vedkommendes Uskikkethed til at indrette og holde en Skole. Mine Herrer Colleger have allerede viist saa store Feil i Planen, at jeg ikke har meget at tilføie. Dog troer jeg at burde gjøre opmærksom paa Grundtvigs i Planen anbefalede historiske Børnelærdom, som i en kjærnefuld Korthed indeholder meget Godt, men der kan omtrent gjøres af den hvad man vil, alt eftersom man udfylder den. Man kunde jo forudsætte at dette vilde skee paa bedste Maade, dersom ikke Planen lærte os, at man hertil vilde benytte Grundtvigs Krønikeriim, som ikke kunne andet end indpræge i Ungdommen falske Forestillinger over Menneskeslægtens Udvikling, en Feil som deres poetiske Fortjenester ikke hæver. Enhver, som ikke er enig med Grundtvig i at holde de mange herlige Mænd, han udskjælder, for Gudsfornægtere, aandeligt Blinde o.s.v., kan umueligen ønske at hans historiske Fremstillinger skulde bibringes Ungdommen.

Særdeles conseqvent af Ansøgeren er det ogsaa, at han ikke nævner Geometrie, og at han vil lade Geographien læse efter en af de sædvanlige Lærebøger, ligesom om denne Videnskab ikke $\mathrm{i}$ de nyeste Tider havde vundet Dyrkere, der behandle den i en langt høiere Aand end den der før har hersket deri.

Vilde man maaskee indvende, at det vilde synes illiberalt at afslaae en videnskabelig Tænkemaade, der afviger fra vor egen, en Leilighed til at prøve sin Kraft, saa svarer jeg, at det er alt for betænkeligt at lade dem gjøre deres Forsøg med Ungdommen. Vi burde vel $\mathrm{i}$ intet Tilfælde være neutrale i denne Sag; men allermindst kunne vi være det under de givne Omstændigheder. Det er ikke enhver tilladt at anlægge en Skole. Staten vil føre Opsigt dermed, hvilket jeg ogsaa troer er det Rette. Der spørges os nu, om vi finde det tilraadeligt at tilstaae Ansøgeren Tilladelse eller ikke. Der er ingen af os, som ikke troer at den paatænkte Skole vil vorde skadelig; vi bør altsaa ret udtrykkeligt sige det.

Jeg troer ikke at dette Votum er i sit Væsen afvigende fra mine forud voterende Collegers; jeg har kun villet foreslaae en ret udtrykkelig Tilkjendegivelse heraf, paa det at de paafølgende Vota kunne vorde ret afgjørende, dersom vi ere saa enige i Sagen som jeg troer.

d. 2. Octob 1832 .

H. C. Ørsted.«

Både Engelstoft og Ørsted havde tidligere haft lejlighed til at beskæftige sig med Grundtvig. Engelstoft skrev i januar I8I6 og i ok- 
tober 1817 erklæringer om Grundtvigs ansøgninger om at blive universitetslærer i nordisk historie og mytologi og fik forhindret, at Grundtvig fik ansættelse ved universitetet ${ }^{21}$ ). Ørsted havde I8I4I 8I5 været i litterær fejde med Grundtvig som følge af dennes angreb på den tyske naturfilosofi, især Schelling, som Ørsted satte megen pris på (Ørsteds 》Imod den store Anklager « (1814), derimod Grundtvigs »Imod den lille Anklager « ( I8I5) ${ }^{22}$ ). Skønt Grundtvig siden havde modereret sine synspunkter, betragtede Engelstoft og Ørsted ham stadig som en fanatiker og mørkemand. Samtidig lod de Muus høre for, at han havde udgivet sin dimisprædiken, som var blevet kritisk anmeldt i »Maanedsskrift for Litteratur « af professor H. N. Clausen og havde givet anledning til syrlige bemærkninger sammesteds af stiftsprovst (senere biskop) i Odense Nicolai Faber. At en tredje »retsindig mand «, sognepræst i Kongens Lyngby Bone Falch Rønne, havde rost den (i »Dansk Religions-Blad«), tog de ikke hensyn til.

Digteren Adam Oehlenschläger, som var professor i æstetik, indskrænkede sig til at erklære: »Aldeles enig med Etatsraad Ørsted.« Den samme erklæring blev afgivet af professor i fransk N.C. L. Abrahams. Botanikeren 7.W. Hornemann stemte for, at planen, ifølge de i påtegningerne anførte grunde, ikke blev antaget; det samme gjorde geologen G. Forchhammer, zoologen 7. Reinhardt og kemikeren $W$. Zeise. Engelstofts kollega som professor i historie, E. C. Werlauff, afviste også planen:

»Vedkommende yttre sig i deres Plan paa saa evasiv ${ }^{23}$ ) en Maade og i Udtryk, der synes at tilkiendegive en saa bestemt Utilbøielighed til at indlade sig paa en nærmere Forklaring af deres Instituts egentlige Organisation, at det, uden Tvivl, fra flere Sider vel maae findes betænkeligt at meddeele dem nogen Anbefaling. Yttringer som den, at $\gg$ Modersmaalet og Historien skulde forfra og hele Skolen igiennem behandles som en Hovedsag «, stemme neppe overeens med vort lærde Underviisningsvæsens almindelige Tendents. - Jeg tiltræder derfor de Herrer Collegers Meening, som finde at Forslaget ei bør anbefales. Med Hensyn til de Lærebøger, der skulde lægges til Grund ved Underviisningen i Dansk, da burde Indsenderne have udtrykt sig mere bestemt, da man baade af Saxos og Snorres Værker, som bekiendt, haver flere ældre og nyere Oversættelser; men jeg formoder, at de af den første ei have meent den

2 I. Herom henvises til Kirkehistoriske Samlinger 5. rk. I $722 \mathrm{ff}$.

22. M. h.t. denne strid henvises til Henning Høirup: Grundtvigs Syn paa Tro og Erkendelse s. $106 \mathrm{ff}$. og Erland Jessen: Striden mellem Grundtvig og H. C. Ørsted I 814-I 5 (Grundtvig-Studier 197 I S. 31 ff.).

23. D. v. s. undvigende. 
gamle Vedelske Oversættelse, som Ampl. $\left.{ }^{24}\right)$. Decanus antager, eller af Snorre den Clausenske ${ }^{25}$ ), men af Begge de Grundtvigske (i 6 Qvartbind), hvilke, saa aandrige de i det Hele end ere, dog næppe kunde kaldes skikkede til det Øiemed, ligesaalidt som samme Forfatters paraphraserende Oversættelse af det gamle angelsaxiske Digt.

d. $8^{\text {de }}$ Oct. 1832 .

Werlauff.»

Botanikeren f.F. Schouw, senere kendt som formand for den grundlovgivende rigsforsamling, afviste ligeledes planen, medens en anden senere politiker, professor i statsøkonomi $C$. N. David, udtalte sig mod planens ophavsmand:

»For at bedømme hvorvidt Planen kunde svare til Hensigten: at forberede Disciplene til Universitetet, maatte den være fuldstændig og ikke blot indskrænke sig til det første Stadium af Underviisningen. - Forsaavidt man kan slutte af de nærværende data, og forsaavidt jeg i denne Sag tør have nogen Stemme, synes mig at der er Grund til stor Tvivl om at Maalet vil naaes og derhos Anledning til at forudsætte en stor Ensidighed i den Udvikling man vilde give Børnenes Evner.

d. I3. Octb. 1832 .

Schouw.

Jeg er fuldkommen enig med Etatsraad Ørsted, at naar Staten fører Opsyn med Underviisningsvæsenet, saa maa der tages ligesaa meget Hensyn til hvem dette betroes som til hvad der skal læres, thi det beroer dog tilsidst paa Lærerens Personlighed hvad der i en Plan angives at skulle læres. Jo mer Lærerens Personlighed derfor gjør det utilraadeligt at betroe Ungdommens Underviisning til ham - og man har vistnok ikke uden Føie hentydet paa hvor fordærveligt det andensteds har været at betroe Underviisningen til Jesuiterne desto nøiere burde man see paa, at Planen er bestemt affattet og udviklet. $\mathrm{Da}$ i det nærværende Tilfælde dette Sidste ingenlunde finder Sted, og der er saa megen grundet Anke mod Ansøgerens Personlighed, hvad hans Kald til Ungdommens Ledning angaaer, saa stemmer jeg for at den ansøgte Tilladelse ikke tilstaaes Hr. Candidat Muus.

G. N. David.«

Sibberns kollega som professor i filosofi, digteren Poul Moller, sluttede sig til dem, der afviste planen:

»Af mine Hrr. Collegers ovenstaaende Erklæringer seer jeg, at Nogle have antaget, at de skulde yttre deres Mening om, hvorvidt det var tilraadeligt at tilstaae den ansøgte Tilladelse, Andre havde derimod holdt for, at det var nok, naar de yttrede dem om Planens Hensigtsmæssighed eller Uhensigtsmæssighed. Til det sidste Partie vil jeg helst holde mig og erklærer mig da fuldkommen

24. Forkortelse af Amplissimus, højtærede.

25. Der menes den norske præst Peder Glaussøns oversættelse af Heimskringla, udg. 1633 af Ole Worm. 
overbeviist om, at en saadan Underviisningsanstalt ikke vilde svare til sin Bestemmelse. At gaae nærmere ind paa dens i Øine faldende Misgreb, som alt ere udhævede af de Foregaaende, anseer jeg for overflødigt.

Poul Møller.«

Engelstoft gav senere sin erklæring følgende tilføjelse:

»Efter at have læst de senere Paategninger, tilføier jeg, at jeg aldeles tiltræder Hr. Etatsr. Ørsteds Votum, ligesom jeg paa den meest bestemte Maade maa fraraade Ansøgningens Bevilling, med den udtrykkelige Erklæring, at en saadan Skole under saadanne Personligheders Deeltagelse, Styrelse og Indvirkning vilde efter Facultetets Overbeviisning blive et høist skadelig Institut.

d. 5 . Nov. 1832 .

Engelstoft.«

Inden for det filosofiske fakultet var der enighed om at fraråde oprettelsen af en lærd skole efter den foreslåede plan, men med forskellige begrundelser, som det kan ses af de citerede udtalelser. Flertallet, nemlig Sibbern, Madvig, F. C. Petersen, Hornemann, Forchhammer, Reinhardt, Zeise, Werlauff, Schouw og Poul Møller, nøjedes med at afvise planen som utilfredsstillende og lod muligheden åben for at tillade en skole efter en anden plan. Et mindretal, nemlig Engelstoft, Ørsted, Oehlenschläger, David og Abrahams, vilde ikke blot afvise planen, men også ansøgeren og hans bagmænd, først og fremmest Grundtvig.

Sibbern sendte 29. oktober sagen tilbage til rektor; i sin følgeskrivelse $^{26}$ ) gjorde han rede for de forskellige opfattelser i fakultetet:

»Det vil af de mange og til deels udførlige Erklæringer, som af Facultetets Medlemmer derover ere givne, sees, at Ingen har kunnet finde bemeldte Plan værdig til nogen Approbation eller Anbefaling, men at alle tvertimod er enige at møde den med en bestemt Misbilligelse. Men, imedens Nogle have villet, at man paa det Bestemteste burde gjøre Alt for at hindre et Forsøg paa dens Iværksættelse, have Andre været uvisse, om hvorvidt dette turde involvere et større Indgreb i den almindelige borgerlige Frihed, end at man burde andrage derpaa, og have indskrænket sig til at yttre, at, dersom det tillades Ansøgeren og hans Medarbeidere at gjøre Forsøget, denne Tilladelse da maatte gives saaledes, at det bestemt tilkjendegives, at man ikke kunde finde, at Planen kunde billiges.«

Sagen gik nu til Konsistorium. Engelstoft forsøgte som medlem af dette $\mathrm{i}$ sin ovenfor citerede erklæring af 5 . november at få denne forsamling til at tage afstand fra Grundtvig og dennes tilhængere,

26. Findes vedlagt erklæringerne (se noterne 4 og $\mathrm{I} 8$ ). 
men det lykkedes ikke. Konsistorium vedtog følgende i sit møde 7 . november ${ }^{27}$ ):

»Ansøgningen tilligemed Planen samt det philos. Facultets Betænkning tilstilles Direcionen, med Bemærkning af Consist., ligesom Pluraliteten i Facultetet, finder den af Cand. Muus indsendte Plan til en Underviisningsanstalt aldeles uantagelig, og at Cons. følgelig maa fraraade, at en Skole blev oprettet efter de i samme indeholdte Grundsætninger.«

Rektor meddelte ı. november Universitets- og Skoledirektionen Konsistoriums beslutning, idet han samtidig sendte sagen tilbage til den. Direktionen fulgte ligesom Konsistorium det filosofiske fakultets flertal; kun i en bemærkning om, at matematik ikke var nævnt som undervisningsfag, tog den hensyn til Ørsteds erklæring. Dette blev meddelt Muus 24. november :

»Til Gand. Theol. Muus.

I en hertil indgiven Ansøgning af 30 . Aug. d. A. har De anholdt om Tilladelse til i Forening med Pastor Grundtvig og Licentiatus theolog. Fenger her i Staden at aabne en Skole for lærd Underviisning efter en med Ansøgningen fulgt Plan.

Direct. har herover indhentet Consist. og det philosophiske Facultets Betænkning, og saavel dette Sidstes som Consist. Medlemmer have været enige $i$ at ansee den fremlagte Underviisningsplan deels som ufuldstændig, i det der ikke er opgivet, hvorledes Underviisningen siden skulde skride frem til andre Discipliner, deels som uhensigtsmæssig, i det der mod samme er bemærket, at dersom man endog til et Forsøg vilde prøve at begynde med Underviisningen i de lærde Sprog med Græsk istedetfor Latin, da vilde det Nygræske snarere forvirre end fremme Disciplene ved Studiet af det Gammelgræske, at det $\mathrm{Ny}$ græske ikke er af den Vigtighed for Disciplene, at de skulde anholdes til at lære det som et levende Sprog, og at Tiden derved vilde borttages fra gavnligere Underviisning, at det med Hensyn til Sproget ikke kan ansees tienligt at lægge Johannes Evangelium til Grund ved Underviisningen, og at dette Evangelium i andre Henseender er mindre skikket til at gjennemgaaes med saa unge Discipler, end f. Ex. Mathæi Evangelium; at Oversættelser af Saxo eller islandske Skribenter ikke ere skikkede til at anvendes som Grundlag for Underviisningen i det danske Sprog, og at de angivne Lærebøger i Historien ansees mindre passende ved Underviisningen i et videnskabeligt Institut, og at Mathematik ikke er anført blandt Underviisningsgjenstandene.

Da Dir. ganske maa erkjende Rigtigheden af de Indvendinger som af Consist. og det philos. Facultet ere gjorte mod den indsendte Plan, og da den er saa afvigende fra Indretningen i andre lærde Skoler og Instituter, at de efter hiin Plan underviiste Discipler ikke - som De ogsaa selv har bemærket - vilde

27. Acta Consistorii XXIV 2 I 2 f. (Københavns Universitets arkiv nr. 85, RA). 28. Direktionens kopibog $1832 \mathrm{nr}$. I I03 (RA). 
passe ind i disse, saafremt Forældrene siden skulde ønske at anbringe deres Børn deri, saa findes der ingen Anledning til allerunderd. at andrage paa at Tilladelsen forundes Dem til i Overensstemmelse med samme at aabne nogen Skole.«

Dette afslag på Muus' ansøgning gjorde ende på Grundtvigs forhåbninger om en lærd skole, som han kunne sætte sine sønner i. Han opgav derefter ethvert forsøg på at reformere den lærde skole efter sine synspunkter og koncentrerede sig fra nu af om den højskole, som han ønskede oprettet i Sorø. En efterklang af den strandede plan om en grundtvigsk lærd skole findes i Grundtvigs artikel »Den latinske Stil« i »Nordisk Kirke-Tidende« 1834 , hvor han betegnede det som en synd imod børn at forlange, at de skulle samle kundskab af bøger, før de kunne forstå dem med lethed, og at de skulle hitte rede $\mathrm{i}$ fremmede sprog, før de kendte vendingerne $\mathrm{i}$ deres eget, som var det eneste levende oplysningsmiddel, der gaves for dem; derefter fortsatte $\operatorname{han}^{29}$ ):

»Man kan efter samme Grund-Sætning begynde paa Græsk længe før paa Latin, da den Græske Tanke-Gang og Ord-Føining ligger Vores mange Mile nærmere end den Romerske, og da Man paa Græsk har anderledes baade morsomme, nyttige og ærbare Bøger at give dem i Haand end i det forbistrede Latin.«

For Fenger fik hans deltagelse $i$ planen om en grundtvigsk lærd skole den konsekvens, at han gik glip af det teologiske professorat, som var blevet ledigt I831, da N. Fogtmann blev biskop i Ribe. $\mathrm{Da}$ dette professorat skulde besættes, udtalte det nedsatte bedømmelsesudvalg i marts 1833 , at Fenger »ved sin eiendommelige Aandsretning synes mindre skikket til akademisk Docent $\left.\ll^{\mathbf{3 0}}\right)$.

Muus opgav ikke tanken om en lærd skole, hvor græsk skulle træde i stedet for latin, og hvor der skulle gøres forsøg med undervisning i nygræsk i forbindelse med oldgræsk. Han ønskede at undersøge dette spørgsmål nærmere og ansøgte derfor 31 . december 1832 Fonden ad usus publicos om støtte til en rejse til München, der under den græskbegejstrede kong Ludvig I var blevet et centrum for græske studier $\left.{ }^{31}\right)$. Her fik han blankt afslag. Fondens direktion udtalte i sin forestilling 22. marts $\left.1833^{32}\right)$ :

29. Haandbog i N. F. S. Grundtvigs Skrifter I I 3.

3o. F. Elle Jensen anf. værk s. 36 .

31. Ansøgningen er trykt Fonden ad usus publicos. Aktmæssige Bidrag til Belysning af dens Virksomhed, udg. af Rigsarkivet III $299 \mathrm{ff}$.

32. Fondens journal 33 I/8 (RA). 
»Directionen skulde imidlertid allerunderdanigst formene, at der maatte udfordres særdeles Anbefalinger, for at et Andragende af en saa særegen Natur kunde komme i Betragtning; men Supplicanten har ikke fremlagt en eneste Anbefaling. Man kan saaledes ikke tillade sig allerunderdanigst at anbefale Supplicanten til allernaadigst Understøttelse til en Reise i et Øiemed, som har mødt saa bestemt Modsigelse saavel af Directionen for Universitetet og de lærde Skoler som af Consistorium og det philosophiske Facultet.«

I overensstemmelse med denne forestilling fik Muus ingen bevilling af Fonden ad usus publicos, da de årlige understøttelser af den blev fordelt I3. april $\left.{ }^{33}\right)$. Alligevel lykkedes det ham i sommeren 1833 at komme til München og studere i nogle måneder ved det græske institut der. I et brev af 26 . august $1833^{34}$ ) meddelte han Grundtvig sine erfaringer under studierne i München. Samtidig med sin erkendelse af sprogets betydning for skolen følte han straks, at der intet kunne udrettes til gavns med børnene, hvis han og andre kom hjem med en mundfuld nygræsk, men man ville kun forvirre dem og »befordre Dødens store Herredømme ved at lege med nogle Livsgnister og bilde os selv og Andre ind, at det er Livets rene Flamme«. Derefter opgav Grundtvig tanken om at gøre nygræsk til de lærdes sprog.

Af den skæbne, som forslaget til en grundtvigsk lærd skole fik, kan ses, at både Københavns Universitets filosofiske fakultet og Universitets- og Skoledirektionen var præget af en konservatisme, som ikke tillod nogen form for »forsøgsundervisning«. Forslaget vakte nogen opmærksomhed i samtiden: biskop Fogtmann skrev 20. oktober $183^{2}$ fra Ribe til Peder Hjort ${ }^{35}$ ):

»Fremdeles veed De vel, at Grundtvig, Fenger og Muus ville oprette en Skole med jus dimittendi efter en ny Plan, ifølge hvilken Græsk skulde træde i Stedet for Latin, og Dansk læses efter Grundtvigs Oversættelse af Saxo o.s. v.《

Snart blev forslaget glemt; da Peder Hjort I869 udgav dette brev i »Udvalg af Breve fra Mænd og Qvinder«, skrev han i en anmærkning: »Om denne Sammenblanding af Nasjonalskhed og Romerhad har jeg aldrig siden kunnet erfare noget Bestemt.«

33. Iflg. Fondens kopibog meddelt Muus 18 . april 1833 .

34. Grundtvigarkivet fasc. 465 VII I (Kgl. Bibl.).

35. P. Hjort: Udvalg af Breve fra Mænd og Qvinder II 115. 